\title{
What (if Anything) Can Developing Countries Learn from South Korea?
}

\author{
Thomas M. Domjahn ${ }^{1}$ \\ ${ }^{1}$ Department of Politics, University of Constance, Baden-Württemberg, Germany \\ Correspondence: Thomas Domjahn, Department of Politics, University of Constance, Constance, \\ Baden-Württemberg, Germany. Tel: 49-176-9621-0017. E-mail: Thomas.Domjahn@uni-konstanz.de
}

\author{
Received: November 25, 2012 Accepted: January 10, 2013 Online Published: March 8, 2013 \\ doi:10.5539/ach.v5n2p16 \\ URL: http://dx.doi.org/10.5539/ach.v5n2p16
}

\begin{abstract}
The economic development of South Korea since 1960 is one of the biggest success stories in the history of development. In just a few decades, South Korea transformed itself from an agricultural society to an industrialized nation exporting high-technology products such as cars, TVs, mobile phones or computers. Furthermore, after more than two decades of authoritarian rule South Korea changed relatively peacefully to a democratic society in 1987.

On the other hand, many developing countries in Africa, Latin America or South Asia still face economic stagnation and enormous development problems: Poverty, inequality, bad health, a low life expectancy, illiteracy, ethnic and religious conflicts and discrimination of women are a daily occurrence. Observing these large differences in the development level of South Korea and today's developing countries, this article explores, what numerous underperforming countries can learn from the South Korean development model.

This article argues that it will be very difficult, if not impossible, for today's developing countries to imitate the South Korean development model by simply adopting similar policies and formal institutions because, apart from conventional explications, informal institutions shaped by Confucianism ("Asian values") and specific historical circumstances played a key role in the economic development of South Korea. Nevertheless, there are still some lessons to be learnt from South Korea.
\end{abstract}

Keywords: South Korea, economic development, developing countries, formal institutions, informal institutions, Asian values, Confucianism, institutional transplantation

\section{Introduction}

The economic and societal development of South Korea since the 1960s is without doubt a success story. In just a few decades, South Korea transformed itself from an underdeveloped country to an industrialized nation exporting high-technology products like cars, TVs, mobile phones and computers. South Korea's chaebols (conglomerates) like Samsung, Hyundai or LG are well known throughout the world. Moreover, after more than two decades of dictatorship South Korea transformed relatively peacefully to a democratic country in 1987 . The population of South Korea is one of the best educated in the world and income in South Korea is distributed very equally compared to the rest of the world. While South Korea has reached a development level equivalent to that of Spain or Italy, its communist neighbor North Korea is one of the world's poorest countries. The divergent long-term development path of South and North Korea compared to the USA is shown in the graph below (Note 1).

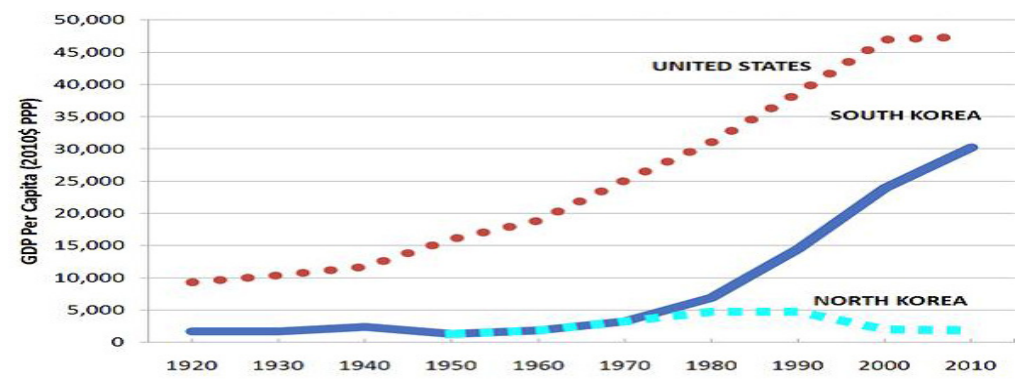

Figure 1. The economic development of South and North Korea in US-\$ (PPP) from 1920-2010 compared with the USA (source: www.newgeography.com) 
The Asian crisis in 1997, or "IMF crisis" as Koreans call it, caused a slowdown of economic development in East Asia, but compared to other countries hit by the crisis, South Korea recovered relatively well and continued to grow economically after the crises but at a reduced rate. In any case, the Asian crisis should not blur the positive evaluation of the long-term development performance of South Korea and the other "Asian Dragons" Taiwan, Singapore and Hong Kong as Léon (1998, p. 5) rightly stresses.

"For many Western observers the Asian crisis not only means the interruption of an impressive process of growth, but the end of a model of development. In my opinion, an ounce of caution is not out of place. Inasmuch as economic development is a long-term process, the development performance of East Asia should be analyzed in a historical perspective, that is to say, at least from 1950 to present."

While South Korea and several other East Asian countries influenced by Confucian culture closed or are closing the development gap to the world's most developed countries (Note 2), many countries in Africa, Latin America or South Asia still face economic stagnation and enormous development problems. Poverty, inequality, bad health, a low life expectancy, illiteracy, ethnic and religious conflicts and discrimination of women are a daily occurrence in many developing countries.

Observing these large differences in the development level of South Korea and today's developing and emerging countries, the question is obvious: What (if anything) can the numerous underperforming countries in Latin America, Africa or South Asia such as, say Mexico, Colombia or Argentina, Morocco, Ghana or South Africa and India, Pakistan or Bangladesh learn from the South Korean development model? Of course, one has to be precise about what the South Korean development consists of, as many divergent interpretations exist. "Simply advising a society to 'follow the Korean model' is a little like advising an aspiring basketball player to 'follow the Michael Jordan model'. To make use of someone else's successful performance at any task, one needs to be able to break this performance down into its component parts so that one can see what each part contributes to the whole, which aspects of this performance are imitable and, of these, which are worth imitating." (Lucas, 1993, p. 252) So, in the course of this article an analysis of the salient features of the South Korean development model will be presented before turning to asking what lessons can be drawn from this development model for today's developing countries.

As explaining economic development can be characterized metaphorically as "bathing in an ocean of independent variables" (Léon, 1998, p. 5), there are always many reasons why a country succeeds or fails economically. So the debate should be on the relative importance of different determinants of economic development. In this article it will be argued, that apart from conventional explications, informal institutions shaped by Confucianism played an important role in the economic development of South Korea. As most developing countries in other cultures don't have similar informal institutions, for them the success of South Korea will be hard to imitate. However, there are still some lessons to be learnt from South Korea.

The article is organized in the following way: Chapter two analyzes the central features of the South Korean development model that are unique to South Korea and East Asia and therefore very difficult to imitate by other countries. Chapter three presents a more optimistic view and explores in what way the South Korean experience can guide the development strategy of developing countries in spite of different informal institutions. The article concludes by summarizing the major issues discussed (chapter 4).

Before proceeding, the term "institution" should be defined at least broadly, as it will be central to the argument. Following the famous definition of Douglass North, institutions can be defined as "the rules of the game in a society or, more formally they are the humanly devised constraints that shape human interaction." (North 1990, p. 3) Institutions can be designed centrally by the state or can evolve unintended. In a different way from natural laws, institutions are always made (intentionally or unintentionally) by persons and can, at least in principle, be changed (cf. Erlei, Leschke, \& Sauerland, 2007, p. 22). Formal institutions are in general codified, i.e. written down, and enforced by the state, while informal institutions are uncodified and not enforced by the state. Examples of informal institutions include morals, religious norms, customs and traditions. Generally speaking, informal institutions change more slowly than formal institutions (cf. Roland, 2000; North, 1990, p. 36ff.; Williamson, p. 595ff.). Another prime example of informal institutions is Confucian ethics.

\section{Why the Economic Success of South Korea Will Be Difficult to Reproduce in Other Developing Countries}

In 1993, Leymarie and Tripier published a book entitled "Maroc: le prochain dragon?" (Morocco: The next dragon?) arguing that Morocco could follow the development path of the "Asian Dragons". Bowditch (1999) puts forward a similar thesis in respect to Ghana. In this chapter it will be argued that it will be very difficult to reproduce South Korea's success for any developing country because of specific informal institutions and 
favorable historical circumstances in the South Korean development process. Although it is not impossible that a country can catch-up like South Korea has done (who would have thought in 1960 that South Korea could?), the probability that the South Korean development model could work in today's developing countries is very low.

\subsection{Development Dictatorship}

In contrast to many developing countries, South Korea first developed economically and only later transformed to a democracy, after having reached a respectable level of economic development. From 1961 to 1987 South Korea was under authoritarian rule of general Park Chung-Hee (until his assassination in 1979) and his successors. This period is sometimes called "developmental dictatorship" (cf. Lee, 2003) as political leaders repressed the population and guided the economy in order to promote economic development.

Most of today's developing countries in Latin America, Africa and South Asia (e.g. India) are (more or less functioning) democracies. Even in the MENA region, which has been a stronghold of authoritarian government, a democratic transition following the events of the "Arab Spring" seems to be possible (cf. Sakbani, 2011; Way, 2011). So even if authoritarian East Asian governments of South Korea or Singapore must be evaluated positively from an economic point of view, this authoritarian model is for political reasons no longer an attractive option for today's democratic development countries like Brazil or Argentina. "The South Korean, T.D. state fostered economic growth vigorously while preventing the workers from participation and consumption. This exclusionary aspect of bureaucratic authoritarianism may not be attractive at all even to our colleagues in Sao Paulo and Buenos Aires." (Han, 1995, p. 7) Many countries in Africa and Latin America have made negative experiences with authoritarian rule, so that the citizens of most developing countries want more, not less democracy. The development dictatorship in South Korea might have been appropriate ex-post from an economic point of view, but this model cannot be recommended to today's developing countries.

\subsection{Ethnic Homogeneity}

Korea is one of the countries with the highest ethnic homogeneity in the world. For this reason, compared to most developing countries, Korea has always had a high social cohesion. This made social cooperation, for example between the state and South Korean chaebols, much easier. Social trust and social capital is higher than in most developing countries. Even if there were always protests against the government, especially by students during the reform process and catch-up development period in the 60s, 70s and 80s, on the whole South Koreans acted in concert. People identify with their nation and their companies understanding economic development as an individual as well as societal goal. This social cohesion is strengthened by the rivalry with North Korea and Confucian ethics which stress the importance of a harmonious and well-ordered society.

On the other hand, most developing countries, especially in Sub-Saharan Africa, have a very heterogeneous population and low social capital. Ethnic conflicts and limited social trust slow-down economic and societal development. Of course, ethnic and linguistic diversity does not lead necessarily to ethnic conflicts as the positive example of Kenya, with over 40 different ethnic groups, shows. But "good governance" and fast economic and political reforms are facilitated by a more homogeneous population (cf. Easterly \& Levine, 1997).

It should be added that variable "ethnic homogeneity" has historical roots (e.g. colonization) and is exogenous from the point of view of today's developing countries, i.e. leaders can deal with ethnic diversity, but they cannot change it (apart from splitting the country like Sudan in 2011). However, while South Korea as a resource poor country was disadvantaged in respect to exploiting natural resources, it had a comparative advantage to most developing countries because of its homogeneous population. Developing a hard-working society with high social trust and a high commitment to the nation and its companies will be hard, if not impossible, in an ethnically divided country with different informal institutions as for example South Africa or Mexico (cf. Domjahn, 2012, pp. 73ff).

\subsection{Education}

South Korea's population is one of the most highly educated in the world. Its results in the worldwide PISA and TIMS studies are well above the OECD average. Over seven percent of South Korea's GDP is invested in education. Private investment in education amounts to 2.8 percent of GDP which is the highest value of all OECD countries. What is special to South Korea are its informal institutions rooted in Confucian ethics which place a high value on education very. Confucius' famous "Analects" (Note 3) starts with the following citation of the "Master": "To learn, and then, in its due season, put what you have learned into practice - isn't that still a great pleasure?" (Confucius, ca. 475-221 B.C., p. 3) Of course one should not equate Confucius' writings with today's informal institutions. Informal Institutions are dynamic entities that change in the course of decades and centuries. But the high demand for education is one of the features of Confucianism which are still present in all 
societies shaped by Confucian ethics. In particular, there is a high demand for education in South Korea, Asia's most Confucian country (cf. Kern, 2005; Maul \& Maul, 2004, p. 138ff.).

It should also be added that South Korea's population was already well-educated compared to other developing countries even before the catch-up development started in the 1960s. For example the primary school enrolment rate in 1956 was an impressive 95 percent. In the preceding decades more and more money was invested not only in primary education but successively in secondary and tertiary education. On the one hand, human capital increase can be seen as an input to economic development, which made the shift in production structure to more sophisticated products possible. On the other hand, it is also an output because more and more private and public money is available to spend on education.

The development strategy to promote education is not unique to South Korea. But in other countries this policy has not been as successful as in South Korea.

"Many other nations, such as Argentina, Brazil and Mexico, have used investment in education as a developmental strategy. However, the expansion of the South Korean educational system was unique because of the rapid and sustained growth at all educational levels, which was strong enough to support sustained economic and industrial development." (Ramires \& Rubio, 2010, p. 76f.).

This shows that the same policy can lead to different results in two countries if informal institutions diverge. The demand for education in South Korea and other Confucian countries was higher than in most non-Confucian countries which facilitated human capital accumulation in South Korea. Countries where the intrinsic demand for education is too low have to give extrinsic incentives for human capital accumulation as for example Mexico does with its Oportunidades program. In Mexico, welfare is only transferred to poor families if parents send their kids to school (cf. Todaro, 2011, pp. 404-407). In South Korea, a government intervention like this was not necessary, so that informal institutions facilitated "good governance".

In this respect, Confucianism is very similar to Protestantism. As Becker and Woessmann (2009) show, the Protestant ethic promotes education. Other religions are less conductive to human capital accumulation. For example in most Muslim countries there are slow-moving informal institutions that hinder women's success in the education sector. This leads to high rates of illiteracy of women in most Muslim countries. E.g. in Morocco 60 percent of all females are illiterate (cf. Pudelko \& Bhargava, 2005; Domjahn, 2012, p. 119ff).

In conclusion, human capital accumulation in South Korea was facilitated by informal institutions shaped by Confucian ethics. Developing countries which want to learn from South Korea have to keep in mind that a similar education policy as South Korea was able to use would lead to other results in a country with different informal institutions.

If policymakers want to apply the lessons of East Asia's experiences, it is not enough to merely imitate the economic and institutional aspects..., they must also factor in the cultural aspects that played a part in East Asia's achievements. That is not to say that they need to adopt Confucian tradition. Rather, it is to remind them that they need to realize the effects brought into play by Confucian tradition." (Liang, 2010, p. 233)

\subsection{Hard Work ("Asian values”)}

Another similarity of the Protestant ethic and the Confucian ethic is the emphasis on hard work and discipline in the sense of Weber (1920). The catch-up development in the 60ies and 70ies was only possible because South Korea's population worked very hard for relatively low wages, six days a week. The commitment of South Koreans to their companies, especially if they were working for chaebols, was higher than in non-Confucian countries. Only because of its informal institutions, valuing hard work, discipline and loyalty, sometimes summed up under the label "Asian values" (cf. Hahm, 2001), could South Korea offer its rather simple commodities such as textiles relatively cheap in the world market. South Korea, only later shifted its production structure to more sophisticated products. Still today, the work load in South Korea is one of the highest of all OECD countries. By the way, this is not only true for workers, but also for students and pupils who sometimes study up to 16 hours a day to prepare their A-levels (cf. Brinkmann, 2011).

Most developing countries cannot resort to such a highly motivated work force like South Korea did during its catch-up development, not to speak of developed countries e.g. in Europe where people have developed post-materialist values (cf. Inglehart, Basáñez \& Halman, 2004, p. 13ff.) including a very high leisure preference. As a consequence, because of higher labor costs, these countries cannot offer comparably cheap products like South Korea did. A copy of the South Korean export strategy would not lead to the same success as the production factor work is not as abundant as in South Korea. Economic incentives have to replace Confucian informal institutions which motivate hard work. 
On the other hand, the loyalty of workers to their companies in East Asia is not one-sided. A "hire-and-fire" mentality like in the USA does not exist in East Asian business culture. Companies care more for their staff and even continue to employ old employees after their performance fades. This is especially true for the Japanese business culture but also, although to a lesser extent, for South Korean business ethics. "In Japan, both for the company and for the individual, employment was a lifetime commitment similar to marriage." (Morishima, 1982, p. 114) This feature can be interpreted as reflecting the Confucian ideal of mutual obligation of principals and agents.

\subsection{Compatibility of Confucian Informal Institutions with Western Formal Institutions}

Last but not least, South Korea had the comparative advantage that its informal institutions were more compatible with Western formal institutions like capitalism, rule of law, the separation of church and state, and democracy than those in other non-Western cultures. Confucianism is a relatively pragmatic, flexible, secular and adaptive thought system. Metaphysical ideas, such as god or life after death, are widely lacking. For example Confucius responds to a question by a student about serving ghosts and spirits: "You haven't learned to serve the living, so how could you serve ghost?" (Confucius, ca. 475- 221 B.C., p. 116) As a consequence, conservative religious forces did not block economic and political reforms during the catch-up development. In other parts of the world, the same reform pace would not have been possible.

„While in other parts of the world traditional religions, be it Hinduism, Islam, or Buddhism, continue to exert enormous influence on politics and economics, this is rarely the case in East Asia. In a sense, East Asians have accepted the 'secular' culture of the West, capitalism, liberalism and democracy much more easily and to a much greater extent than almost any other civilizations of the world." (Hahm, 2001, p. 271)

Every Asian country influenced by Confucianism which started market reforms and adopted an export strategy, be it South Korea, Japan, China, Hong Kong, Vietnam or Taiwan, developed very successfully in the following decades, so that the combination of Confucianism and capitalism seems to be a success formula for economic development.

On the other hand, one has to be cautious not to overstate the role of informal institutions, culture and social capital for economic development. Even if South Korean informal institutions have been praised for being conductive to economic development, culture alone cannot trigger a catching-up development process if it is not accompanied by economic and political reforms. This article therefore does not state that "culture makes almost all the difference" as Landes (2000) does. It is the interplay of formal and informal institutions which determines economic development. A simple example will help to make this point: North Korea in 1950 had exactly the same informal institutions as South Korea but could not develop because of poor formal institutions and bad policies. Moreover, because informal institutions are suppressed and cannot flourish freely in North Korea, a part of its social capital has been lost during the last 60 years of dictatorship (cf. León, 2011; Acemoglu, 2004).

"Confucianist culture cannot be the only answer to East Asia's past success, which was mainly brought about by such economic factors as effective government regulation, strong export promotion, better use of the external environment after World War II, macroeconomic stability, efficient use of resources and so on." (Shixue, 2003, p. 29)

To conclude, generally speaking one can say that it will be hard for today's developing countries to reproduce the South Korean development path because informal institutions and historical circumstances not existent in most of today's developing countries played an important role and should therefore not be underestimated. At any rate, it would not be possible simply to adapt the same development policies and formal institutions to repeat South Korea's economic success. In the next paragraph it will be shown what developing countries can learn from the South Korean development model nevertheless.

\section{What Developing Countries Can Learn from South Korea Nevertheless}

The previous paragraph presented a rather pessimistic view of what is possible for today's developing countries: There seems to be little hope for most developing countries to become "the next dragon" or "the next tiger". The combination of fast economic and political reforms with supportive informal institutions was nearly unique to East Asia. However, knowledge about the South Korean development model is still valuable for today's developing countries. Some beneficial conclusions can be drawn from the analysis of the development path of South Korea even if these insights are not very revolutionary and will not lead to a paradigm shift in development economics. Unfortunately, a magic formula for economic development, applicable to all developing countries, does not exist. 


\subsection{First Capitalism and Development, then Democracy}

South Korea first introduced economic reforms, and only later, after having developed economically, made up for democratic reforms. The economic success of China and Singapore also shows that democracy is not a prerequisite for economic growth. Econometric studies confirm this thesis (cf. Barro, 1996; Barro, 1997). While it has been argued above, that democratic countries or countries in a democratic transition like Mexico, Argentina, South Africa or India should not make a step backwards to a development dictatorship à la South Korea for political reasons, countries with authoritarian or hybrid regimes can learn from South Korea's experience. The lesson is not to enforce democracy too early at any price. Once the living standard rises, education also increases and democratic reforms will be easier to implement. A country without a democratic tradition will probably not succeed in introducing democracy over night as informal institutions persist and adapt only slowly. The failure will even be worse if democracy is imposed from outside like the recent cases of Iraq and Afghanistan show. For a developing country without a democratic tradition, such as Morocco, it is more important to enhance the living standard and education while reducing inequalities, promoting the separation of the state and the church and giving more capabilities to girls and women. Democratic reforms should be done only incrementally so that informal institutions have enough time to change. So even when the West has a political interest in fast democratization of developing countries, the timing and sequencing of democratic reforms have to be compatible with the institutional status quo of the respective country. A "one size fits all approach" is not appropriate as more and more development economists stress (cf. Dröge, 2008, p. 74; Domjahn, 2012, p. 153ff; Boettke, Coyne \& Leeson, 2008, p. 324ff.; Pies, 2009, p. 25ff.)

"Even if it sounds strange to Western economists, free markets and the corresponding political, civil, and legal rights might not lead to immediate growth in every society." (Dobler, 2011, p. 207)

"Because incompatibilities between internal and external institutions greatly increase the costs of governing, the formal (external) institutions that can be set and modified by political will should not be completely at odds with the prevalent informal (internal) institutions." (Voigt, 2005, p. 61)

\subsection{Export Orientation}

Apart from formal and informal institutions, the economic success of South Korea and the other Asian Tigers has been largely due to their consequent export policy (cf. World Bank, 1993). An export orientation seems to be a necessary (although not a sufficient) condition for economic growth. Countries which do not open up economically to the world market remain poor. Extreme examples are North Korea, Myanmar or Cuba (cf. Léon, 2011).

Although this insight is not new to modern development economics, the case of South Korea and the other Asian Tigers confirms that developing countries have to build up an export strategy framed by institutional reforms. Import substitution strategies and policies based on dependencia theories (cf. Cardoso, 1979) seem to be out-of-date in the light of the success of the Asian Tigers.

\subsection{Variety of Capitalism}

Equally important and also widely accepted is the need for developing countries to build up domestic markets in order to promote economic competition. But the case of the Asian Tigers shows that there is more than one single standard economic policy to achieve economic growth. For example South Korea succeeded with large enterprises (chaebols) while Taiwan had rather small and medium-sized enterprises. Hong-Kong implemented an almost pure laissez-faire policy while the government in South Korea practiced a pragmatic policy-mix with regular state interventions in the economic process. These examples show that there is a variety of capitalism that can lead to economic growth. Although a market system is a necessary condition for economic growth, economic policies do not have to be necessarily designed according to the neo-liberal Washington Consensus. Every developing country has to find its own policy-mix and the status quo as well as the political and economic culture of the respective country have to be taken into account.

\subsection{Social and Economic Equality}

South Korea not only had a very ethnic homogeneous population. Its society was also very equal in respect to income and wealth distribution. Today, South Korea's gini coefficient, according to the CIA world factbook, is about 0.3 which is comparably low. There are only a few countries in the world where family income is distributed more equally than in South Korea. While ethnic homogeneity is exogenous to today's developing countries the income distribution can be changed by social redistribution policies.

Developing countries with a very high gini coefficient as for example Mexico, Brazil or South Africa, should try to reduce inequality. Of course this is easier said than done as economic growth is a prerequisite for 
redistribution measures. But it has to be kept in mind that large inequalities reduce social cohesion and can lead to criminality and a decrease of social capital. A fast economic reform process supported by a large majority of the population as in South Korea will be hard to implement in a country lacking social cohesion and social trust.

\subsection{Education}

It has been argued above, that informal institutions shaped by Confucian ethics accelerated the human capital accumulation in South Korea. Human capital, in turn, was a key to South Korea's fast economic development (cf. Acevedo, 2008; Maksymenko \& Rabbani, 2008; Lee, 2000).

The importance of human capital for economic development in general is widely accepted (cf. Bils \& Klenow, 2000; Krueger \& Lindahl, 2001; Prichett, 2001; Romer, 1989).

"A greater amount of educational attainment implies more skilled and productive workers, who in turn increase an economy's output of goods and services. An abundance of well-educated human resources also helps to facilitate the absorption of advanced technologies from developed countries. In addition, the level and distribution of educational attainment has a strong impact on social outcomes, such as child mortality, fertility, education of children, and income distribution." (Barro \& Lee, 2001, p. 541)

As a consequence, countries lacking informal institutions that promote the demand for education have to give incentives for human capital accumulation. For example the Oportunidades Program cited above which works rather well in Mexico could be implemented in other developing countries outside Latin America. Some countries in Africa (Malawi and Sambia) and South Asia (Bangladesh) have already started similar initiatives. Other countries should follow. Especially those countries, whose informal institutions cause a gender bias, i.e. where an underinvestment in education for girls exists (e.g. Morocco), should give incentives to parents to send their daughters to school.

\section{Conclusion}

It has been argued that it will be very hard, if not impossible, for today's developing countries to follow the South Korean development path and to become "the next tiger" because a particular combination of formal and informal institutions and historical circumstances supported the South Korean catch-up development. South Korea had the advantage of having a high social cohesion, and an ethnical homogenous highly motivated and well-educated population. Therefore the catch-up development with fast economic reforms under authoritarian rule ("development dictatorship") was successful at least from an economic point of view. The same policies in another country lacking South Korea's informal institutions would have lead to other (probably worse) results. Therefore, South Korea's development model cannot be transferred blindfold to today's developing countries.

Nevertheless, there is hope that high economic development can be achieved outside the West and East Asia. The economic success of countries like Botswana (cf. Acemoglu \& Robinson, 2012, p. 404ff.) shows that high growth rates do not have to be restricted to these two successful regions. Developing countries can learn from South Korea that education, an equal income distribution, an export orientation and free market reforms are significant factors for economic development, while democracy does not have to be introduced rashly, at any price, especially when the population is lacking the necessary education and democratic political culture.

The analysis and the derived advice for today's developing countries in this article have been rather general and not country-specific as the group of developing countries is very heterogeneous in respect to its institutions, culture, geography and other important development variables. Nevertheless, as newspapers and magazines all over the world regularly speak of "the next dragon" or "the next tiger" if a developing country achieves high growth rates for some years a warning seems to be appropriate: The long-term development performance of South Korea and the other Asian Tigers will be very hard to reproduce as supportive informal institutions ("Asian values") cannot be found in most of today's developing countries. However, economic development is possible with different sets of formal and informal institutions. But the expectation to develop as quickly and continuously as the Asian Tigers might be a too optimistic and therefore not helpful aim for most of today's developing countries. More realistic country-specific intermediate development goals should be set.

\section{References}

Acemoglu, D., \& Robinson, J. (2012). Why Nations fail. The Origins of Power, Prosperity, and Poverty. New York, NY: Crown Business.

Acemoglu, D., Johnson, S., \& Robinson, J. (2004). Institutions as the Fundamental Cause of Long-run Growth. NBER Working Paper 10481. Cambridge, MA. 
Acevedo, S. (2008). Measuring the Impact of Human Capital on the Economic Growth of South Korea. Journal of the Korean Economy, 9(1), 113-139.

Barro, R. (1996). Democracy and Growth. Journal of Economic Growth, 1(1), 1-27. http://dx.doi.org/10.1007/BF00163340

Barro, R. (1997). Determinants of Economic Growth: A Cross-Country Empirical Study. NBER Working Paper 5698. Cambridge, MA.

Barro, R., \& Lee, J. (2001). International Data on Educational Attainment: Updates and Implications. Oxford Economic Papers, 53(3), 541-563. http://dx.doi.org/10.1093/oep/53.3.541

Becker, S., \& Woessmann, L. (2009). Was Weber wrong? A Human Capital Theory of Protestant Economic History. Quarterly Journal of Economics, 124(2), 531-596. http://dx.doi.org/10.1162/qjec.2009.124.2.531

Bils, M., \& Klenow, P. (2000). Does Schooling Cause Growth?. American Economic Review, 90(5), 1160-1183. http://dx.doi.org/10.1257/aer.90.5.1160

Bowditch, N. (1999). The Last Emerging Market: From Asian Tigers to African Lions?. Westport, CT: Praeger Publishers.

Boettke, P., Coyne, C., \& Leeson, P. (2008). Institutional Stickiness and the New Development Economics. American Journal of Economics and Sociology, 67(2), 331-358.

Brinkmann, B. (2011, December 5). Abitur in Südkorea. 16 Stunden am Tag lernen. Süddeutsche Zeitung.

Cardoso, F. E. (1979). Dependency and Development in Latin America. Berkeley, CA: University of California Press.

Confucius (ca. 475- 221 B.C.). The Analects. Washington, DC: Counterpoint.

Dobler, C. (2011). The Impact of Formal and Informal Institutions on Economic Growth. A Case Study on the MENA Region. Frankfurt, Germany: Peter Lang.

Domjahn, T. (2012). Informelle Institutionen und wirtschaftliche Entwicklung. Eine konzeptionelle und empirische Analyse unter besonderer Berücksichtigung der Entwicklungspfade von Mexiko, Südkorea und Marokko. Bayreuth, Germany: Verlag für Nationalökonomie, Management und Politikberatung.

Dröge, A. (2007). Informelle Institutionen in ökonomischen Entwicklungsprozessen. Der Zuckersektor in Guyana. Baden-Baden, Germany: Nomos.

Easterly, W., \& Levine, R. (1997). Africa's Growth Tragedy: Policies and Ethnic Divisions. Quarterly Journal of Economics, 112(3), 1203-1250. http://dx.doi.org/10.1162/003355300555466

Erlei, M., Leschke, M., \& Sauerland, D. (2007). Neue Institutionenökonomik. Stuttgart, Germany: Schäffer-Poeschel.

Hahm, C. (2001). Why Asian Values?. Korea Journal, 41(2), 265-274.

Han, S. (1995). Economic Development and Democracy: Korea as a New Model?. Korea Journal, 35(2), 5-17.

Inglehart, R., Basáñez, M., \& Halman, L. (2004). Human Beliefs and Values. A cross-cultural sourcebook based on the 1999-2002 values survey. Mexico City, Mexico: Siglo XXI.

Kern, T., \& Köllner, P. (Eds.) (2005). Südkorea und Nordkorea. Einführung in Geschichte, Politik, Wirtschaft und Gesellschaft. Frankfurt am Main, Germany, Campus Verlag.

Kern, T. (2005). In T. Kern, \& P. Köllner, Südkoreas Bildungs- und Forschungssystem.

Krueger, A., \& Lindahl, M. (2001). Education for Growth: Why and for Whom. Journal of Economic Literature, 39(4), 1101-1136. http://dx.doi.org/10.1257/jel.39.4.1101

Landes, D. (2000). Culture Makes Almost All the Difference. In L. Harrisson, \& S. Huntington (Eds), Culture matters, How Values Shape Human Progress. New York, NY: Perseus Books.

Lee, N. (2000). Education and Economic Growth in Korea, 1966 to 1997. Journal of Applied Business Research, 16(4), 83-93.

Lee, B. (2006). Developmental dictatorship and the Park Chung-hee era. Paramus, NJ: Homa \& Sekey Books.

León, J. L. (1998). Culture, the State, and Economic Development in Korea and Mexico. Retrieved January 15, 2010, from http://orpheus.ucsd.edu/las/studies/pdfs/leon.pdf 
León, J. L. (2011). Similar Policies, Different Outcomes: Two Decades of Economic Reforms in North Korea and Cuba, Korea Economic Institute. Academic Paper Series, 6(4).

Leschke, M. (2010). Ökonomik der Entwicklung. Bayreuth, Germany: Verlag für Nationalökonomie, Management und Politikberatung.

Leymarie, S., \& Tripier, J. (1993). Maroc: le prochain dragon?. Paris, France: Karthala.

Liang, M. (2010). Confucianism and the East Asian Miracle. American Economic Journal: Macroeconomics, 2(3), 206-234. http://dx.doi.org/10.1257/mac.2.3.206

Lucas, R. (1993). Making a Miracle. Econometrica, 61(2), 251-272.

Maksymenko, S., \& Rabbani, M. (2008). Economic Reforms, Human Capital, and Economic Growth in India and South Korea: A Cointegrative Analysis. University of Pittsburgh, Department of Economics, Working Papers: 361 .

Maul, I., \& Maul, H. (2004). Im Brennpunkt: Korea. Munich, Germany: Beck.

Morishima, M. (1982). Why has Japan 'succeeded'?. Cambridge, England: Cambridge University Press.

North, D. (1990). Institutions, Institutional Change and Economic Performance. Cambridge, England: Cambridge University Press.

Pies, I. (2009). In I. Pies, \& M. Leschke, Theoretische Grundlagen demokratischer Wirtschafts- und Gesellschaftspolitik - Der Ansatz von Douglass North.

Pies, I., \& Leschke, M. (Eds.) (2009). Douglass Norths ökonomische Theorie der Geschichte. Tübingen, Germany, Mohr Siebeck.

Pudelko, M., \& Bhargava, N. (2005). The Influence of Islam on the Economic Development of Muslim Countries. Iktisat Isletme ve Finans (Journal of Economic Business and Finance), 20(235), 16-28.

Prichett, L. (2001). Where has all the Education gone?. World Bank Economic Review, 15(3), 367-391. http://dx.doi.org/10.1093/wber/15.3.367

Ramirez, L., \& Rubio, J. (2010). Culture, Government and Development in South Korea. Asian Culture and History, 2(1), 71-81.

Roland, G. (2004). Understanding Institutional Change: Fast-Moving and Slow-Moving Institutions. Studies in Comparative International Development, 38(4), 109-131. http://dx.doi.org/10.1007/BF02686330

Romer, P. (1989). Human Capital and Growth: Theory and Evidence. NBER Working Paper no. 3173, Cambridge, MA.

Sakbani, M. (2011). The revolutions of the Arab Spring: Are democracy, development and modernity at the gates?. Contemporary Arab Affairs, 4(2), 127-147. http://dx.doi.org/10.1080/17550912.2011.575106

Shixue, J. (2003). Cultural Factors and Economic Performance in East Asia and Latin America. LABEA working papers.

Todaro, M. (2011). Economic Development. New York, NW: Prentice Hall.

Way, L. (2011). Comparing the Arab Revolts: The Lessons of 1989. Journal of Democracy, 22(4), 13-23. http://dx.doi.org/10.1353/jod.2011.0068

Weber, M. (1920). In Dirk Kaesler (Eds.), Die protestantische Ethik und der Geist des Kapitalismus. München, Germany: Beck.

Williamson, O. (2000). The New Institutional Economics, Taking Stock, Looking Ahead. Journal of Economic Literature, 38(3), 595-613. http://dx.doi.org/10.1257/jel.38.3.595

World Bank. (1993). The East Asian Miracle - Economic Growth and Public Policy. Oxford, England: Oxford University Press.

\section{Notes}

Note 1. A more detailed analysis of the development path of South Korea can be found in Domjahn (2012).

Note 2. Apart from the already cited "dragons" Indonesia, Malaysia and China could also be named.

Note 3. There are no written publications of Confucius left. The Analects have been compiled by his pupils in the centuries following his death. 